\title{
GEN1 Gene
}

National Cancer Institute

\section{Source}

National Cancer Institute. GEN1 Gene. NCI Thesaurus. Code C124101.

This gene plays a role in the resolution of Holliday junctions. 